\title{
A 2/1 sunitinib dosing schedule provides superior antitumor effectiveness and less toxicity than a 4/2 schedule for metastatic renal cell carcinoma: A systematic review and meta- analysis
}

\author{
Huan Deng \\ The First Affiliated Hospital of Nanchang University \\ Lianli Zeng \\ The First Affiliated Hospital of Nanchang University \\ Qian Wu \\ The First Affiliated Hospital of Nanchang University \\ Li Wang \\ The First Affiliated Hospital of Nanchang University \\ Zhengdong Hong \\ The First Affiliated Hospital of Nanchang University \\ Fengming Yi \\ The First Affiliated Hospital of Nanchang University \\ Yiping Wei \\ The First Affiliated Hospital of Nanchang University \\ Wenxiong Zhang ( $\nabla$ zwx123dr@126.com ) \\ The Second Affiliated Hospital of Nanchang University https://orcid.org/0000-0003-2962-0847
}

\section{Research article}

Keywords: Renal cell carcinoma; Sunitinib; Alternative dosing; Effectiveness; Meta-analysis.

Posted Date: July 1st, 2019

DOI: https://doi.org/10.21203/rs.2.10894/v1

License: (c) (i) This work is licensed under a Creative Commons Attribution 4.0 International License. Read Full License

Version of Record: A version of this preprint was published at Frontiers in Oncology on March 6th, 2020. See the published version at https://doi.org/10.3389/fonc.2020.00313. 


\section{Abstract}

Background The standard sunitinib schedule to treat metastatic renal cell carcinoma (mRCC) is 4 weeks on/2 weeks off (4/2). However, some studies revealed intolerable adverse events (AEs) in patients on this schedule. An alternative schedule, 2 weeks on/1 week off (2/1), may overcome this issue. This meta-analysis was performed to compare the effectiveness and toxicity between the 2/1 and 4/2 sunitinib dosing schedules. Methods We acquired relevant studies by searching PubMed, ScienceDirect, the Cochrane Library, Scopus, Ovid MEDLINE, Embase, Web of Science, and Google Scholar. Our main endpoints included overall survival (OS), progression-free survival (PFS), objective response rate (ORR), disease control rate (DCR), and AEs. Results We identified 9 medium- and high-quality studies. Both schedules were effective for mRCC, with comparable OS and similar ORR. However, the $2 / 1$ schedule had better PFS (hazard ratio $(H R)=0.81,95 \%$ confidence interval [Cl]: 0.66-0.99, P= 0.04), higher $\mathrm{DCR}$ (risk rate $(\mathrm{RR})=1.22,95 \% \mathrm{Cl}$ : 1.01-1.47, $\mathrm{P}=0.04$ ) and fewer dosage interruptions ( $\mathrm{RR}=0.60,95 \% \mathrm{Cl}: 0.43-0.84$, $\mathrm{P}=0.003$ ). Additionally, the $2 / 1$ schedule elicited fewer specific severe $A E s$, including thrombocytopenia/platelet disorder, handfoot syndrome, hypertension and fatigue. In our subanalysis, PFS was better among East Asians using the 2/1 schedule than among other populations ( $\mathrm{HR}=0.75,95 \% \mathrm{Cl}: 0.58-0.98, \mathrm{P}=0.03$ ), and patients administered an initial dosage of $50 \mathrm{mg} / \mathrm{d}$ on the $2 / 1$ schedule had superior PFS ( $H R=0.76,95 \% \mathrm{Cl}: 0.59-0.97, \mathrm{P}=0.03$ ) than those others. Conclusions These findings suggest that the $2 / 1$ schedule is more suitable for mRCC than $4 / 2$, due to superior PFS, better DCR and fewer AEs. Nevertheless, more large-scale studies with good quality are needed.

\section{Background}

As the second most common tumor in the urological system, kidney cancer is estimated to account for 73820 cancer cases and result in 14770 deaths in $2019^{[1,2]}$. In addition, over $30 \%$ of patients are found to have metastasis at initial diagnosis, and the expenditure for treating metastatic renal cell carcinoma (mRCC) reached nearly $\$ 1.6$ billion in these selected countries ${ }^{[3,4]}$. The National Comprehensive Cancer Network (NCCN) guidelines have approved sunitinib as a standard first-line antiangiogenic agent to treat $\mathrm{mRCC}[5]$.

Sunitinib, a small molecular tyrosine kinase inhibitor (TKI), has suggested superior efficacy and safety profile among mRCC patients in a randomized controlled trial $(\mathrm{RCT})^{[6]}$. The traditional schedule for Sutent administration is 4 weeks on/2 weeks off $(4 / 2)$ with a dosage of $50 \mathrm{mg} / \mathrm{d}^{[7]}$. Motzer et al. indicated that this treatment schedule (4/2) had an improved PFS, higher response rates and fewer adverse events (AEs) than interferon-alpha in a phase III RCT ${ }^{[8]}$. However, some sunitinib-related severe AEs from the 4/2 schedule led to poor tolerability and reduced health-related quality of life for some mRCC patients, so these AEs need to be monitored carefully ${ }^{[9]}$. This problem requires further research in detail. A new schedule, 2 weeks on/1 week off $(2 / 1)$, may solve this problem ${ }^{[10]}$. In a phase I study, Britten et al. reported that a $2 / 1$ Sutent schedule had similar drug accumulation but less toxicity than the $4 / 2$ schedule ${ }^{[11]}$. Although both dosing schedules showed clinical benefits among mRCC patients, the optimal dosing schedule is still controversial. An RCT indicated that the $2 / 1$ schedule had less toxicity with similar

progression-free survival (PFS) when compared with the $4 / 2$ schedule ${ }^{[12]}$. However, in a recent study at a major Comprehensive Cancer Center, Atkinson et al. suggested that alternative schedules had superior PFS (hazard ratio (HR) $0.49,95 \%$ confidence interval [Cl]: 0.36-0.67, $\mathrm{P}<0.0001)$ and better overall survival $(\mathrm{OS})(\mathrm{HR}=0.48,95 \% \mathrm{Cl}: 0.34-0.69, \mathrm{P}<0.0001)$ than traditional schedules $^{[13]}$.

To address this discrepancy, we performed meta-analyses of pertinent articles comparing the antitumor effectiveness and toxicity of the two dosing schedules (2/1 and 4/2) of sunitinib to provide the latest evidence-based suggestions for mRCC.

\section{Methods}

We conducted the meta-analysis following the PRISMA (Preferred Reporting Items for Systematic Review and Meta-analysis) guidelines. 


\section{Search strategies}

All pertinent studies were obtained through the following databases: PubMed; ScienceDirect; the Cochrane Library; Scopus; Web of Science; Embase; Ovid MEDLINE; and Google Scholar. We used these terms as follows: "kidney neoplasm", "sunitinib", and "alternative dosing schedule". The complete search strategy in these electronic databases is listed in Table S2. The references of all qualifying studies were searched for potentially eligible articles. Included articles were required to be written in English.

\section{Selection criteria}

Studies which obeyed these criteria would be enrolled in accordance with PICOS (Participants, Intervention, Control, Outcome, Study design): (1) Participants: patients diagnosed with mRCC (defined as having distant metastasis apart from the primary lesion); (2) Intervention and Control: compared 2/1 schedule versus 4/2 schedule; (3) Outcome: PFS, OS, objective response rate (ORR), disease control rate (DCR), complete response rate (CR), partial response rate (PR); stable disease rate (SD) and AEs; (4) Study design: RCT or retrospective study (RS); and (5) were written using English.

The reviews without original data, conference abstracts, case reports, meta-analysis, animal experiments, and articles with repeated data would be excluded.

\section{Date extraction}

The data were independently extracted by two investigators (Deng and Fan) to obtain the following information: first author, publication time, nation, number of participants, participants' features (age, histological types, pretreatment, metastatic sites), antitumor effectiveness index (PFS, OS, ORR, DCR), and AEs (any grade AEs, grade 3-4 AEs). All disagreements were discussed with a third investigator (Zhang) until a consensus was reached. Considering the number and time of events at the same time, we used hazard ratios (HRs) rather than odds ratios to analyze PFS and OS. We obtain HRs and $95 \%$ Cls directly from Cox multivariate survival analyses. Otherwise, HRs and $95 \%$ Cls were calculated based on Kaplan-Meier curves constructed as indicated by the protocol from Tierney et $\mathrm{al}^{[14]}$.

\section{Quality evaluation}

The quality of the RCT was appraised by the 5-point Jadad scale including 3 main aspects: randomization, masking and accountability of all participants. Articles scoring 3-5 points were regarded as high-quality ${ }^{[15]}$.

RS' qualities were appraised through the 9-point Newcastle-Ottawa Scale containing these aspects: selection, comparability and exposure. Articles with scores of 8 or 9 were regarded as high quality, while scores of 6 and 7 indicated medium quality ${ }^{[16]}$.

We also made use of GRADE (Grades of Recommendations Assessment, Development and Evaluation) for evaluating therapeutic strategy and the study design regarding the survival, response rates, and toxicity. The GRADE is categorized into 4 classes (high, medium, low, and very low) ${ }^{[17]}$.

\section{Statistical analysis}

We performed this meta-analysis using RevMan (version 5.2) and STATA (version 12.0). HRs with $95 \%$ Cls were chosen to analyze PFS and OS (HR>1 supports 4/2, HR<1 supports 2/1). We used risk ratios (RRs) with $95 \%$ Cls to analyze ORR, DCR 
( $R R>1$ supports $2 / 1, R R<1$ supports $4 / 2$ ), and $A E s$ ( $R R>1$ supports $4 / 2, R R<1$ supports $2 / 1$ ). We conducted a subgroup analysis to determine whether the outcomes would be different according to nationality, treatment line, initial dosage, study quality, and study design. We evaluated heterogeneity through the $\chi^{2}$ test and $P$ statistic. If $P>50 \%$ or $P<0.10$ in the $\chi^{2}$ test, showing significant heterogeneity, the random-effects model was applied; otherwise, the fixed-effects model was used. The sensitivity analyses of PFS, OS, ORR and DCR were performed to strengthen robustness. Publication bias was assessed with Begg's test and Egger's test. $P<0.05$ showed statistical significance.

\section{Results}

Search results and study qualities

Figure 1 illustrates the process of selecting studies. Finally, 9 studies involving 774 patients (2/1 schedule, 264; $4 / 2$ schedule, 510) were selected for this meta-analysis ${ }^{[12,18-25]}$. One study was an RCT, and the remaining eight studies were RSs. Five articles were considered high quality (1 RCT scored four points using the Jadad scale, and 4 RSs scored eight points using the Newcastle-Ottawa Scale). Four RSs were considered medium quality (3 articles scored seven points, and 1 article scored six points; Table S3). Furthermore, most of our outcomes were low or very low according to the GRADE scale (Table S4). Table 1 lists the basic features and major assessment indexes of the nine included articles.

\section{Antitumor effectiveness}

We appraised the antitumor effectiveness between the $2 / 1$ and $4 / 2$ schedules according to PFS, OS, ORR, and DCR.

Eight articles compared PFS (heterogeneity: $P=0 \%, P=0.57$ ). The $2 / 1$ group had an improved PFS compared to that of the $4 / 2$ group (HR=0.81, 95\% Cl: 0.66-0.99, P= 0.04; Figure 2A).

Six articles compared OS (heterogeneity: $P=0 \%, P=0.91$ ). No significant differences existed between the two schedules (HR= 1.00, 95\% Cl: 0.95-1.05, P = 0.97; Figure 2B).

Five articles were used to compare ORR (heterogeneity: $P=20 \%, P=0.29)$. No significant differences existed $(\mathrm{RR}=0.91,95 \% \mathrm{Cl}$ : 0.64-1.29, P= 0.58; Figure 3A).

Four articles were used to compare DCR (heterogeneity: $P=44 \%, \mathrm{P}=0.15)$. The $2 / 1$ schedule had a higher $\mathrm{DCR}(\mathrm{RR}=1.22,95 \%$ Cl: 1.01-1.47, P= 0.04; Figure 3B) than the 4/2 schedule.

We also analyzed response rates in detail owing to the contradictory results of ORR as well as DCR. Five articles compared CR (heterogeneity: $P=0 \%, P=0.74$ ). No significant differences existed between the groups (RR=0.93, 95\% $\mathrm{Cl}: 0.31-2.79, \mathrm{P}=0.90$; Figure $3 \mathrm{C}$ ). Five studies compared $\mathrm{PR}$ (heterogeneity: $P=36 \%, \mathrm{P}=0.18$ ). No significant differences existed (RR= $0.90,95 \% \mathrm{Cl}$ : $0.61-1.33, \mathrm{P}=0.60$; Figure 3D). Four articles compared SD (heterogeneity: ${ }^{2}=23 \%, \mathrm{P}=0.27$ ), and Figure $3 \mathrm{E}$ shows that the $2 / 1$ schedule had more SD ( $R R=1.66,95 \% \mathrm{Cl}: 1.19-2.32, \mathrm{P}=0.003)$ than the $4 / 2$ schedule.

\section{Toxicity}

The toxicity of sunitinib between the $2 / 1$ and $4 / 2$ schedules based on any grade as well as on grade 3-4 AEs was compared. In addition, subgroup analyses of the ten most common toxic events were conducted.

Four studies compared AEs of any grade (heterogeneity: $P=87 \%, P<0.0001)$. No significant differences existed $(\mathrm{RR}=0.96,95 \%$ Cl: 0.85-1.09, P= 0.55; Figure 4A). 
Four articles compares grade $3-4 \mathrm{AEs}$ (heterogeneity: $\left.P^{2}=33 \%, \mathrm{P}=0.21\right)$. No significant differences existed $(\mathrm{RR}=0.71,95 \% \mathrm{Cl}$ : 0.58-0.87, $\mathrm{P}=0.001$; Figure 4B).

Some mRCC patients experienced dose reductions, dose interruptions or dose discontinuations during their treatment. Three studies compared dose reductions (heterogeneity: $R^{2}=58 \%, P=0.09$ ), and no significant differences existed between the two schedules (RR= 0.97, 95\% Cl: 0.71-1.34, $\mathrm{P}=0.87$; Figure $5 \mathrm{~A}$ ). Two studies compared dose interruptions (heterogeneity: $P=0 \%, \mathrm{P}=$ 0.53 ), and the $2 / 1$ group had fewer dose interruptions than the $4 / 2$ group ( $R R=0.60,95 \% \mathrm{Cl}$ : 0.43-0.84, $P=0.003$; Figure 5B). Additionally, two articles compared dose discontinuations (heterogeneity: $P=92 \%, P=0.0006$ ), and no significant differences existed (RR= 0.55, 95\% Cl: 0.09-3.21, $P=0.51$; Figure 5C).

In the subanalysis of the ten most common AEs (in order of incidence: leukopenia, thrombocytopenia/platelet disorder, handfoot syndrome, neutropenia, anemia, hypothyroidism, stomatitis/mucositis, hypertension, fatigue, and abdominal pain/diarrhea), the outcomes of AEs of any grade demonstrated that there was no significant difference in the rates of leukopenia, thrombocytopenia/platelet disorder, and hypothyroidism. Regarding any grade AEs, the 4/2 group had higher incidences of hand-foot syndrome ( $R R=0.70,95 \% \mathrm{Cl}: 0.60-0.82, \mathrm{P}<0.0001)$, neutropenia (RR= 0.62, 95\% Cl: $0.49-0.79$, $\mathrm{P}<0.0001$ ), anemia ( $R R=0.80,95 \% \mathrm{Cl}: 0.67-0.95, P=0.01)$, stomatitis/mucositis ( $R R=0.67,95 \% \mathrm{Cl}: 0.54-0.83, P=0.0003)$, hypertension ( $R R=0.65,95 \% \mathrm{Cl}: 0.53-0.79, \mathrm{P}<0.0001)$, fatigue ( $R R=0.67,95 \% \mathrm{Cl}: 0.59-0.77, \mathrm{P}<0.00001)$, and abdominal pain/diarrhea ( $R R=0.67,95 \% \mathrm{Cl}: 0.48-0.92, \mathrm{P}=0.02$; Table 2 ) than $2 / 1$. The outcomes of grade $3-4$ AEs demonstrated that no significant differences were found for leukopenia, neutropenia, anemia, hypothyroidism, stomatitis/mucositis, or abdominal pain/diarrhea between the two schedules. Within grade 3-4 AEs, the 4/2 schedule had a higher instance of thrombocytopenia/platelet disorder $(R R=0.53,95 \% \mathrm{Cl}: 0.29-0.98, P=0.04)$, hand-foot syndrome ( $R R=0.61,95 \% \mathrm{Cl}: 0.38-0.98$, $\mathrm{P}=0.04)$, hypertension ( $R R=0.45,95 \% \mathrm{Cl}: 0.26-0.77, \mathrm{P}=0.004)$, and fatigue ( $R R=0.42,95 \% \mathrm{Cl}: 0.24-0.73, \mathrm{P}=0.002 ; \mathrm{Table} 3)$ than $2 / 1$.

\section{Subgroup analysis}

To determine whether the antitumor effectiveness of the $2 / 1$ and $4 / 2$ schedules were different, we calculated the pooled outcomes of PFS, OS, and ORR in accordance with nationality, treatment line, initial dosage, study quality, and study design (Table 4). Intriguingly, the pooled results of PFS found that the $2 / 1$ schedule had longer PFS (HR= $0.75,95 \% \mathrm{Cl}: 0.58-0.98, \mathrm{P}=$ $0.03)$ among East Asians than other mRCC patients on the same schedule and superior PFS ( $\mathrm{HR}=0.76,95 \% \mathrm{Cl}: 0.59-0.97, \mathrm{P}=$ 0.03 ) among participants who used an initial dosage of $50 \mathrm{mg} / \mathrm{d}$. Other results of our subanalysis were all robust.

\section{Sensitivity Analysis}

PFS (Figure S1A) and OS (Figure S1B) were both robust, with no estimated value exceeding the $95 \%$ Cls. Moreover, the sensitivity analysis of the ORR (Figure S2A) and DCR (Figure S2B) also suggested that there were both consistent outcomes.

\section{Publication Bias}

We did not find any proof of publication bias when analyzing PFS (Begg's test, $P=0.711$, Egger's test, $P=0.656$; Figure S3A), OS (Begg's test, $P=0.452$; Egger's test, $P=0.583$; Figure S3B), ORR (Begg's test, $P=1.000$; Egger's test, $P=0.360$; Figure S4A) or DCR (Begg's test, $P=0.734$; Egger's test, $P=0.528$; Figure S4B).

\section{Discussion}


Admittedly, the traditional schedule (4/2) of sunitinib has been associated with some unsatisfactory outcomes, especially severe toxicity, in some mRCC patients. As an alternative, the 2/1 schedule may tackle this dilemma and provide some substantial benefits for mRCC patients. This was the first meta-analysis comparing the effectiveness and toxicity of $2 / 1$ versus $4 / 2$ sunitinib dosing schedules among patients with mRCC. Our pooled results of nine included studies demonstrated that there was no significant difference in OS and ORR, but the 2/1 schedule was associated with longer PFS, better DCR and fewer drug interruptions. In addition, we found a lower incidence of severe AEs, including thrombocytopenia/platelet disorder, hand-foot syndrome, hypertension, and fatigue, in the 2/1 group than in the 4/2 group. In our subanalysis, the pooled outcomes of studies from East Asian patients reported that the $2 / 1$ schedule was associated with better PFS compared with the same schedule in other mRCC patients, and the 2/1 schedule had also superior PFS among patients who used the initial dosage of $50 \mathrm{mg} / \mathrm{d}$ than those administered another initial dosage.

Survival is the most critical point that we should take into account when comparing the $2 / 1$ and $4 / 2$ groups. The pooled outcomes demonstrated that there was no significant difference in OS between the $2 / 1$ and $4 / 2$ schedules, but the $2 / 1$ schedule had an association with improved PFS. In fact, a multicenter phase II RCT suggested that the $2 / 1$ sunitinib dosing schedule had a better failure-free survival rate at half a year than the traditional $4 / 2$ schedule ${ }^{[13]}$. According to a recent RS including 108 Chinese participants, Pan et al. reported that therapy with Sutent $50 \mathrm{mg} / \mathrm{d}$ using a $2 / 1$ schedule could offer better PFS among mRCC patients than the standard schedule $4 / 2^{[19]}$. Additionally, Atkinson et al. demonstrated that among mRCC patients using sunitinib as the first-line treatment, an alternative schedule of sunitinib had a superior median PFS compared to a traditional schedule (14.5 months vs. 4.3 months, $P<0.0001)^{[14]}$. One probable reason may be as follows: severe toxicity of the $4 / 2$ schedule, which could significantly reduce patients' tolerability, influence patients' living quality and give rise to unnecessary drug reductions, interruptions or discontinuations; all these negative events may weaken the antitumor effectiveness of sunitinib in patients on the 4/2 schedule. Remarkably, our subgroup analysis indicated that East Asian patients with mRCC may experience superior PFS compared with other patients, and the $2 / 1$ schedule had superior PFS among patients using an initial dosage of $50 \mathrm{mg} / \mathrm{d}$. Admittedly, positive findings in our subgroup analysis revealed a trend. These conclusions must be accepted with caution, especially the outcomes of subanalysis, and additional high-impact, good-quality RCTs with larger cohorts will be needed to confirm our conclusions.

The response rate is an indispensable cornerstone worth considering when choosing the best dosing schedule of sunitinib. Our pooled results showed that the $2 / 1$ schedule was associated with an equivalent ORR to the $4 / 2$ schedule but a higher DCR. Due to these paradoxical results, we performed an elaborate analysis of the response rate among patients with mRCC. Though patients in the 4/2 group had comparable CR and PR to the patients in the $2 / 1$ group, the latter had more SD (RR= $1.66,95 \% \mathrm{Cl}$ : 1.19-2.32, $\mathrm{P}=0.003$ ), which we also regarded as a status of disease control. In light of RECIST 1.1 (Response Evaluation Criteria in Solid Tumors), SD was defined as either a decrease in the overall length of the baseline cancer lesions by less than 30 percent of the initial size or an increase less than 20 percent of the initial size ${ }^{[26]}$. In an RS including 154 Japanese participants, Miyake et al. reported no significant differences in response rates between 2 schedules $(27.6 \% \text { vs. } 25.8 \%, P=0.51)^{[18]}$. Similarly, Din et al. found that both schedules had comparable ORR (23.8\% vs. $28.5 \%)$, but the $2 / 1$ schedule was associated with more SD than the $4 / 2$ schedule $(66.7 \%$ vs. $28.6 \%, P=0.013)$ at delayed assessment ${ }^{[20]}$. In a single arm phase II study, Jonasch et al. reported a relatively high rate of SD (31\%) among patients with $\mathrm{mRCC}^{[27]}$. There is no doubt that we can conclude that the $2 / 1$ schedule had an equivalent ORR (CR+ PR) but a higher SD, which is a significant benefit for patients with mRCC.

The toxicity of sunitinib is also an essential influencing factor when making decisions about $2 / 1$ or $4 / 2$ dosing schedules. Although the 2/1 schedule was not significantly different in dose reductions and dose discontinuations between both dosing schedules, it had fewer dose interruptions (Figure 5). The incidence rates of any grade AEs were not significantly different, but the 4/2 group was associated with higher rates of grade 3-4 AEs than the 2/1 group (Figure 4). In fact, grade 3-4 AEs were a more crucial index of toxicity than grade 1-2 AEs because the compliance of many patients using sunitinib was reduced when grade 3-4 AEs appeared. For grade 3-4 AEs, lower incidences of thrombocytopenia/platelet disorder, hand-foot syndrome, hypertension, and fatigue were reported in the $2 / 1$ group. Undoubtedly, our findings demonstrated that sunitinib-treated patients using the 2/1 schedule had fewer sunitinib-related severe AEs and superior tolerability than those using the $4 / 2$ schedule. In an RS analyzing sunitinib-treated participants switching from the $4 / 2$ schedule to the $2 / 1$ schedule, Najjar et al. suggested that 
therapy on the 2/ 1 schedule had apparently reduced toxicity among patients experiencing AEs $\geq$ grade 3 in the 4/2 group and could prolong treatment duration greatly ${ }^{[28]}$. An RS reviewed mRCC patients who started therapy with sunitinib on the $4 / 2$ schedule and then switched to $2 / 1$ because of severe $A E s$, and this analysis found that patients on the 2/ 1 schedule had higher quality of life and remarkably lower rates of severe AEs ${ }^{[29]}$. Similarly, some recent studies found that compared with the 4/2 schedule, the 2/ 1 schedule conveyed a superior quality of life and better tolerability, as reflected by large reductions in some

specific toxicities ${ }^{[30-32]}$. In addition, Suo et al. showed that the $2 / 1$ group had much lower mean monthly drug costs than the 4/2 schedule (4394 Canadian dollars vs. 5936 Canadian dollars, $\mathrm{P}<0.03)^{[21]}$. Therefore, it is no exaggeration that compared with the $4 / 2$ schedule, the $2 / 1$ schedule of sunitinib was the superior dosing schedule for treating mRCC, which balanced toxicity and survival due to fewer sunitinib-related severe AEs, superior PFS and more SD among patients with mRCC.

To be honest, there were some included studies reporting some sunitinib-treated participants who started treatment using the $4 / 2$ schedule but changed to the $2 / 1$ schedule, and we did not include these patients as either intervention or control groups. There were two main reasons for this. First, the reasons why patients switched from the $4 / 2$ to the $2 / 1$ schedule were varied but may have been due to severe toxicity or disease progression. Second, the time that patients changed from $4 / 2$ to the 2/1 schedule differed, as some patients changed during the first cycle of sunitinib, but other patients changed during later cycles. In brief, the heterogeneity of patients changing from the $4 / 2$ to the $2 / 1$ schedule may be significant, so we believed that it was inappropriate if we included these patients as intervention or control groups.

Some limitations should be taken into account regarding our outcomes. First, the finite number of RCTs (only one) may weaken the quality of these analyses. Second, the number of participants on the two schedules was not large, and this may have resulted in some unreliable estimated values. Third, language bias may exist because all included articles were published in English. Fourth, some outcomes (any grade AEs, dose reductions) had significant heterogeneity, and although they were not the primary index, this might influence the reliability of our conclusions. Fifth, our major outcomes were all low or very low according to the GRADE scale. Sixth, we could not completely control for confounding factors (previous therapy, the number of metastases) because information regarding these factors was sometimes unavailable, but they may have influenced the final results.

\section{Conclusions}

Our meta-analysis demonstrates that the $2 / 1$ schedule has more antitumor benefits (improved PFS, better DCR) than the $4 / 2$ schedule for treating mRCC. Moreover, the $2 / 1$ schedule has less sunitinib-related severe toxicity and better tolerability among patients with mRCC. A 2/1 schedule might produce better PFS among East Asian mRCC patients than in other mRCC patients. In addition, patients administered an initial dosage of $50 \mathrm{mg} / \mathrm{d}$ on a 2/1 schedule may have superior PFS. Nevertheless, the inherent limitations of this meta-analysis suggest that more large-scale high-quality studies are required for better determining the role of sunitinib dose schedules under specific clinical circumstances.

\section{Abbreviations}

4/2: 4-weeks-on and 2-weeks-off; 2/1: 2-weeks-on and 1-week-off; mRCC: metastatic renal cell carcinoma; TKl: tyrosine kinase inhibitor; AEs: adverse effects; HRs: hazard ratios; CR: complete response rate; PR: partial response rate; SD: stable disease rate; ORR: objective response rate; DCR: disease control rate; OS: overall survival; PFS: progression-free survival; RCT: randomized controlled trial; RS: retrospective study; RRs: risk ratios; Cls: confidence intervals; GRADE: Grades of Recommendations Assessment, Development and Evaluation; RECIST: Response Evaluation Criteria in Solid Tumors.

\section{Declarations}

Ethics approval and consent to participate

Not applicable. 
Consent for publication

Not applicable.

Availability of data and material

All data is available in this paper.

Competing interests

The authors declare that they have no competing interests.

Funding

This study was supported by National Natural Science Foundation of China (NSFC), number of grants (81560345), Natural Science Foundation of Jiangxi Province (Grant number: 20161BAB215237). The funding had no role in the design and conduct of the study; collection, management, analysis, and interpretation of the data; preparation, review, or approval of the manuscript; and decision to submit the manuscript for publication.

\section{Authors' contributions}

Huan Deng had full access to all of the data in the manuscript and takes responsibility for the integrity of the data and the accuracy of the data analysis.

Concept and design: All authors.

Acquisition, analysis, or interpretation of data: All authors.

Drafting of the manuscript: Huan Deng and Wenxiong Zhang.

Critical revision of the manuscript for important intellectual content: Huan Deng, Lianli Zeng, Qian Wu, Li Wang, Zhengdong Hong and Fengming Yi.

Statistical analysis: Huan Deng, Lianli Zeng, Qian Wu and Li Wang.

Supervision: Wenxiong Zhang and Yiping Wei.

Acknowledgements: The authors thank professor Bentong Yu, MD (The first affiliated hospital of Nanchang University) for his statistical advice and professor Xiaoshu Cheng, MD, PhD (The second affiliated hospital of Nanchang University) for his data collection.

\section{References}

[1] Siegel RL, Miller KD, Jemal A. Cancer statistics, 2019. CA Cancer J Clin. 2019; 69(1):7-34. 
[2] Ljungberg B, Campbell SC, Choi HY, Jacqmin D, Lee JE, Weikert S, Kiemeney LA. The epidemiology of renal cell carcinoma. Eur Urol. 2011; 60(4):615-21.

[3] Wersäll PJ, Blomgren H, Lax I, Kälkner KM, Linder C, Lundell G, Nilsson B, Nilsson S, Näslund I, Pisa P, Svedman C.. Extracranial stereotactic radiotherapy for primary and metastatic renal cell carcinoma. Radiother Oncol. 2005; 77:88-95.

[4] Gupta K, Miller JD, Li JZ, Russell MW, Charbonneau C. Epidemiologic and socioeconomic burden of metastatic renal cell carcinoma (mRCC): a literature review. Cancer Treat Rev. 2008; 34(3):193-205.

[5] Motzer RJ, Agarwal N, Beard C, Bolger GB, Boston B, Carducci MA, Choueiri TK, Figlin RA, Fishman M, Hancock SL, Hudes GR, Jonasch E, Kessinger A, Kuzel TM, Lange PH, Levine EG, Margolin KA, Michaelson MD, Olencki T, Pili R, Redman BG, Robertson CN, Schwartz LH, Sheinfeld J, Wang J.. NCCN clinical practice guidelines in oncology: kidney cancer. J Natl Compr Canc Netw. $2009 ; 7: 618-630$.

[6] Gore ME, Szczylik C, Porta C, Bracarda S, Bjarnason GA, Oudard S, Hariharan S, Lee SH, Haanen J, Castellano D, Vrdoljak E, Schöffski P, Mainwaring P, Nieto A, Yuan J, Bukowski R. Safety and efficacy of Sunitinib for metastatic renal-cell carcinoma: an expanded-access trial. Lancet Oncol. 2009; 10(8):757-763.

[7] Faivre S, Delbaldo C, Vera K, Robert C, Lozahic S, Lassau N, Bello C, Deprimo S, Brega N, Massimini G, Armand JP, Scigalla P, Raymond E. Safety, pharmacokinetic, and antitumor activity of SU11248, a novel oral multitarget tyrosine kinase inhibitor, in patients with cancer. J Clin Oncol. 2006; 24:25-35

[8] Motzer RJ, Hutson TE, Tomczak P, Michaelson MD, Bukowski RM, Rixe O, Oudard S, Negrier S, Szczylik C, Kim ST, Chen I, Bycott PW, Baum CM, Figlin RA. Sunitinib versus interferon alpha in metastatic renal-cell carcinoma. N Engl J Med. 2007; 356:115-24

[9] Zhou A. Management of sunitinib adverse events in renal cell carcinoma patients: the Asian experience. Asia Pac J Clin Oncol. 2012; 8:132-44

[10] Najjar YG, Elson P, Wood LS. Association of a 2-weeks-on and 1-week-off schedule of sunitinib with decreased toxicity in metastatic renal cell carcinoma. ASCO Meeting Abstracts 2013; 31(6):406.

[11] Britten CD, Kabbinavar F, Hecht JR, Bello CL, Li J, Baum C, Slamon D. A phase I and pharmacokinetic study of sunitinib administered daily for 2 weeks, followed by a 1-week off period. Cancer Chemother Pharmacol. 2008; 61(3):515-24.

[12] Lee JL, Kim MK, Park I, Ahn JH, Lee DH, Ryoo HM, Song C, Hong B, Hong JH, Ahn H. Randomized phase II trial of Sunitinib four weeks on and two weeks off versus Two weeks on and One week off in metastatic clear-cell type renal cell carcinoma: RESTORE trial. Ann Oncol. 2015; 26(11):2300-5.

[13] Atkinson BJ, Kalra S, Wang X, Bathala T, Corn P, Tannir NM, Jonasch E. Clinical outcomes for patients with metastatic renal cell carcinoma treated with alternative sunitinib schedules. J Urol. 2014; 191(3):611-8.

[14] Tierney JF, Stewart LA, Ghersi D, Burdett S, Sydes MR. Practical methods for incorporating summary time-to-event data into meta-analysis. Trials. 2007; 8: 16.

[15] Jadad AR, Moore RA, Carroll D, Jenkinson C, Reynolds DJ, Gavaghan DJ, McQuay HJ. Assessing the quality of reports of randomized clinical trials: is blinding necessary? Control Clin Trials. 1996; 17(1): 1-12.

[16] Wells GA, Shea BJ, O'Connell D. The newcastle-ottawa scale (nos) for assessing the quality of non-randomized studies in meta-analysis. Appl Eng Agric. 2014; 18(6): 727-734.

[17] Mir MH, Changal KH, Aziz SA, Bhat GM, Lone AR. Sunitinib in metastatic renal cell carcinoma (mRCC): a developing country experience. Do our patients behave differently than the Western patients? Int Urol Nephrol. 2016; 48(11):1811-1816. 
[18] Miyake H, Matsushita Y, Watanabe H, Tamura K, Suzuki T, Motoyama D, Ito T, Sugiyama T, Otsukav A. Significance of introduction of alternative dosing schedule for sunitinib during first-line treatment of patients with metastatic renal cell carcinoma. Med Oncol. $2018 ; 35(10): 133$.

[19] Pan X, Huang H, Huang Y, Liu B, Cui X, Gan S, Ye J, Xu D, Chen L, Zhou Q, Li L, Hong Y. Sunitinib dosing schedule 2/1 improves tolerability, efficacy, and health-related quality of life in Chinese patients with metastatic renal cell carcinoma. Urol Oncol. 2015; 33(6):268.e9-15.

[20] Ezz El Din M. Sunitinib 4/2 Versus 2/1 Schedule for Patients With Metastatic Renal Cell Carcinoma: Tertiary Care Hospital Experience. Clin Genitourin Cancer. 2017; 15(3):e455-e462.

[21] Suo A, Iqbal U, Lim J, Lee C, Gesy K, Iqbal N, Abbas T. Outcomes and Drug Costs of Sunitinib Regimens for Metastatic Renal Cell Carcinoma: A Provincial Population-Based Study. Clin Genitourin Cancer. 2017; 15(3):e397-e404.

[22] Kondo T, Takagi T, Kobayashi H, lizuka J, Nozaki T, Hashimoto Y, Ikezawa E, Yoshida K, Omae K, Tanabe K. Superior tolerability of altered dosing schedule of sunitinib with 2-weeks-on and 1-week-off in patients with metastatic renal cell carcinoma-comparison to standard dosing schedule of 4-weeks-on and 2-weeks-off. Jpn J Clin Oncol. 2014; 44(3):270-7.

[23] Zhang X, Sun G, Zhao J, Shu K, Zhao P, Liu J, Yang Y, Tang Q, Chen J, Shen P, Wang J, Zeng H. Improved Long-Term Clinical Outcomes And Safety Profile Of Sunitinib Dosing Schedule With 4/2 Switched To 2/1 In Patients With Metastatic Renal Cell Carcinoma. J Cancer. 2018; 9(18):3303-3310.

[24] Neri B, Vannini A, Brugia M, Muto A, Rangan S, Rediti M, Tassi R, Cerullo C. Biweekly sunitinib regimen reduces toxicity and retains efficacy in metastatic renal cell carcinoma: a single-center experience with 31 patients. Int J Urol. 2013; 20(5):478-83.

[25] Bracarda S, lacovelli R, Boni L, Rizzo M, Derosa L, Rossi M, Galli L, Procopio G, Sisani M, Longo F, Santoni M, Morelli F, Di Lorenzo G, Altavilla A, Porta C, Camerini A, Escudier B; Rainbow Group. Sunitinib administered on 2/1 schedule in patients with metastatic renal cell carcinoma: the RAINBOW analysis. Ann Oncol. 2015; 26(10):2107-13.

[26] Eisenhauer EA, Therasse P, Bogaerts J, Schwartz LH, Sargent D, Ford R, Dancey J, Arbuck S, Gwyther S, Mooney M, Rubinstein L, Shankar L, Dodd L, Kaplan R, Lacombe D, Verweij J. New response evaluation criteria in solid tumours: revised RECIST guideline (version 1.1). Eur J Cancer 2009; 45:228-247

[27] Jonasch E, Slack RS, Geynisman DM, Hasanov E, Milowsky MI, Rathmell WK, Stovall S, Juarez D, Gilchrist TR, Pruitt L, Ornstein MC, Plimack ER, Tannir NM, Rini BI. Phase II Study of Two Weeks on, One Week off Sunitinib Scheduling in Patients With Metastatic Renal Cell Carcinoma. J Clin Oncol. 2018; 36(16):1588-1593.

[28] Najjar YG, Mittal K, Elson P, Wood L, Garcia JA, Dreicer R, Rini BI. A 2 weeks on and 1 week off schedule of sunitinib is associated with decreased toxicity in metastatic renal cell carcinoma. Eur J Cancer. 2014; 50(6):1084-9.

[29] Miyake H, Harada K, Miyazaki A, Fujisawa M. Improved health-related quality of life of patients with metastatic renal cell carcinoma treated with a 2 weeks on and 1 week off schedule of sunitinib. Med Oncol. 2015; 32(3):78.

[30] Bracarda S, Negrier S, Casper J, Porta C, Schmidinger M, Larkin J, Gross Goupil M, Escudier B. How clinical practice is changing the rules: the sunitinib 2/1 schedule in metastatic renal cell carcinoma. Expert Rev Anticancer Ther. 2017; 17(3):227233.

[31] Buti S, Donini M, Bersanelli M, Gattara A, Leonardi F, Passalacqua R. Feasibility, Safety, and Efficacy of an Alternative Schedule of Sunitinib for the Treatment of Patients with Metastatic Renal Cell Carcinoma: A Retrospective Study. Drugs R D. 2017; 17(4):585-596.

[32] Ohba K, Miyata Y, Yasuda T, Asai A, Mitsunari K, Matsuo T, Mochizuki Y, Matsunaga N, Sakai H. Efficacy and safety of sunitinib alternate day regimen in patients with metastatic renal cell carcinoma in Japan: Comparison with standard 4/2 
schedule. Asia Pac J Clin Oncol. 2018; 14(3):153-158.

\section{Tables}

Table 1 Characteristics of included studies

\begin{tabular}{|c|c|c|c|c|c|c|c|c|c|c|c|c|c|}
\hline \multirow{2}{*}{\multicolumn{2}{|c|}{ Study }} & \multirow[t]{2}{*}{ Country } & \multirow[t]{2}{*}{$\begin{array}{l}\text { Study } \\
\text { period }\end{array}$} & \multirow[t]{2}{*}{$\begin{array}{c}\text { Pre- } \\
\text { treatment }\end{array}$} & \multirow[t]{2}{*}{ Groups } & \multirow[t]{2}{*}{$\begin{array}{c}\text { Treatment } \\
\text { line }\end{array}$} & \multirow[t]{2}{*}{$\begin{array}{l}\text { Patients } \\
\text { (n) }\end{array}$} & \multirow{2}{*}{\multicolumn{2}{|c|}{$\begin{array}{c}\text { Initial } \\
\text { dosage }\end{array}$}} & \multirow[t]{2}{*}{$\begin{array}{l}\text { Median } \\
\text { age (y) }\end{array}$} & $\begin{array}{c}\text { CCRCC } \\
\text { (\%) }\end{array}$ & Design & $\begin{array}{c}\text { Score } \\
\text { a }\end{array}$ \\
\hline & & & & & & & & & & & & & \\
\hline 2015 & $\begin{array}{l}\text { Lee } \\
{[12]}\end{array}$ & Korea & $\begin{array}{l}2007.11- \\
2014.02\end{array}$ & NPT, CT & $\begin{array}{c}2 / 1 \\
\text { vs. } 4 / 2\end{array}$ & NA & $38 / 36$ & $\begin{array}{c}50 \\
\mathrm{mg} / \mathrm{d}\end{array}$ & $\begin{array}{c}50 \\
\mathrm{mg} / \mathrm{d}\end{array}$ & $57.0 / 60.0$ & $82 / 94$ & RCT & 4 \\
\hline 2018 & $\begin{array}{l}\text { Miyake } \\
\text { [18] }\end{array}$ & Japan & $\begin{array}{l}2010.01- \\
2017.01\end{array}$ & NPT & $\begin{array}{c}2 / 1 \\
\text { vs. } 4 / 2\end{array}$ & 1 & $47 / 62$ & $\begin{array}{c}50 \\
\mathrm{mg} / \mathrm{d}\end{array}$ & $\begin{array}{c}50 \\
\mathrm{mg} / \mathrm{d}\end{array}$ & NA & $89 / 87$ & RS & 8 \\
\hline 2015 & $\begin{array}{l}\text { Pan } \\
{[19]}\end{array}$ & China & $\begin{array}{l}2009.01- \\
2013.07\end{array}$ & NPT & $\begin{array}{c}2 / 1 \\
\text { vs. } 4 / 2\end{array}$ & NA & $32 / 50$ & $\begin{array}{c}50 \\
\mathrm{mg} / \mathrm{d}\end{array}$ & $\begin{array}{c}50 \\
\mathrm{mg} / \mathrm{d}\end{array}$ & $66.0 / 62.0$ & $84 / 80$ & RS & 8 \\
\hline 2017 & $\begin{array}{l}\text { Din } \\
{[20]}\end{array}$ & Egypt & $\begin{array}{l}2012.01- \\
2016.01\end{array}$ & NPT & $\begin{array}{c}2 / 1 \\
\text { vs. } 4 / 2\end{array}$ & NA & $26 / 30$ & $\begin{array}{c}50 \\
\mathrm{mg} / \mathrm{d}\end{array}$ & $\begin{array}{c}50 \\
\mathrm{mg} / \mathrm{d}\end{array}$ & $49.5 / 49.0$ & $88 / 77$ & RS & 6 \\
\hline 2017 & $\begin{array}{l}\text { Suo } \\
{[21]}\end{array}$ & Canada & $\begin{array}{l}2006.01- \\
2012.12\end{array}$ & NPT & $\begin{array}{c}2 / 1 \\
\text { vs. } 4 / 2\end{array}$ & 1,2 & $9 / 59$ & $\begin{array}{c}50 \\
\mathrm{mg} / \mathrm{d}\end{array}$ & $\begin{array}{c}50 \\
\mathrm{mg} / \mathrm{d}\end{array}$ & $\begin{array}{c}62.3 / 60.8 \\
b\end{array}$ & $100 / 83$ & RS & 7 \\
\hline 2014 & $\begin{array}{l}\text { Knodo } \\
{[22]}\end{array}$ & Japan & $\begin{array}{l}2010.01- \\
2012.12\end{array}$ & NPT & $\begin{array}{c}2 / 1 \\
\text { vs. } 4 / 2\end{array}$ & 1 & $26 / 22$ & $\begin{array}{c}35 \% \\
\text { pts } \\
50 \\
\mathrm{mg} / \mathrm{d}\end{array}$ & $\begin{array}{c}32 \% \\
\mathrm{pts} \\
50 \\
\mathrm{mg} / \mathrm{d}\end{array}$ & $\begin{array}{c}64.6 / \\
62.7 \mathrm{~b}\end{array}$ & $96 / 91$ & RS & 7 \\
\hline 2018 & $\begin{array}{l}\text { Zhang } \\
\text { [23] }\end{array}$ & China & $\begin{array}{l}2008- \\
2015\end{array}$ & NPT & $\begin{array}{c}2 / 1 \\
\text { vs. } 4 / 2\end{array}$ & 1 & $24 / 30$ & NA & NA & $59.5 / 53.5$ & $62 / 73$ & RS & 8 \\
\hline 2013 & $\begin{array}{l}\text { Neri } \\
{[24]}\end{array}$ & Italy & $\begin{array}{l}2008.1- \\
2010.5\end{array}$ & NPT & $\begin{array}{c}2 / 1 \\
\text { vs. } 4 / 2\end{array}$ & NA & $21 / 10$ & $\begin{array}{c}50 \\
\mathrm{mg} / \mathrm{d}\end{array}$ & $\begin{array}{c}50 \\
\mathrm{mg} / \mathrm{d}\end{array}$ & NA & NA & RS & 7 \\
\hline 2015 & $\begin{array}{l}\text { Bracarda1 } \\
{[25]}\end{array}$ & Italy & $\begin{array}{c}2005.11- \\
2013.8\end{array}$ & NA & $\begin{array}{c}2 / 1 \\
\text { vs. } 4 / 2\end{array}$ & 1 & $41 / 211$ & NA & NA & $61.0 / 59.0$ & $88 / 87$ & RS & 8 \\
\hline
\end{tabular}

Abbreviations: NPT: nephrectomy; CT: cytokine therapy; 4/2: 4-weeks-on and 2-weeks-off; 2/1: 2-weeks-on and 1-week-off; RCT: randomized controlled trail; RS: retrospective study; pts: patients; CCRCC: clear-cell renal cell carcinoma; NA: not available.

a RCT was evaluated using the Jadad scale, and retrospective studies were evaluated using the Newcastle-Ottawa Scale.

b mean.

Table 2 Top 10 adverse effects (all grade) associated with $2 / 1$ versus 4/2. 


\begin{tabular}{|c|c|c|c|c|c|c|c|}
\hline \multirow{2}{*}{$\begin{array}{l}\text { Adverse } \\
\text { effects }\end{array}$} & \multirow{2}{*}{$\begin{array}{l}\text { No. of } \\
\text { studies }\end{array}$} & \multirow[t]{2}{*}{ 2/1 group (event/total) } & \multirow[t]{2}{*}{ 4/2 group (event/total) } & \multirow[t]{2}{*}{ RR (95\% CI) } & \multirow[t]{2}{*}{$P$ value } & \multicolumn{2}{|c|}{ Heterogeneity } \\
\hline & & & & & & $I^{2}(\%)$ & $\mathrm{P}$ value \\
\hline Leukopenia & 4 & $86 / 135$ & $111 / 135$ & $0.86[0.73,1.00]$ & 0.05 & 14 & 0.32 \\
\hline Thrombocytopenia & 7 & $124 / 234$ & $224 / 438$ & $0.86[0.70,1.06]$ & 0.15 & 64 & 0.01 \\
\hline \multicolumn{8}{|l|}{ / Platelet disorder } \\
\hline Hand-foot syndrome & 7 & $111 / 234$ & $274 / 438$ & $0.70[0.60,0.82]$ & $\square 0.0001$ & 15 & 0.32 \\
\hline Neutropenia & 5 & $59 / 146$ & $106 / 168$ & $0.62[0.49,0.79]$ & $\square 0.0001$ & 30 & 0.22 \\
\hline Anemia & 6 & $92 / 193$ & $129 / 230$ & $0.80[0.67,0.95]$ & 0.01 & 40 & 0.14 \\
\hline Hypothyroidism & 6 & $89 / 208$ & $188 / 408$ & $0.83[0.69,1.01]$ & 0.06 & 5 & 0.39 \\
\hline Stomatitis/Mucositis & 5 & $67 / 161$ & $205 / 346$ & $0.67[0.54,0.83]$ & 0.0003 & 0 & 0.44 \\
\hline Hypertension & 7 & $88 / 234$ & $227 / 441$ & $0.65[0.53,0.79]$ & $\square 0.0001$ & 32 & 0.18 \\
\hline Fatigue & 7 & $117 / 234$ & $327 / 438$ & $0.67[0.59,0.77]$ & $\square 0.00001$ & 42 & 0.11 \\
\hline Abdominal pain & 7 & $85 / 234$ & $218 / 438$ & $0.67[0.48,0.92]$ & 0.02 & 61 & 0.02 \\
\hline /Diarrhea & & & & & & & \\
\hline
\end{tabular}

Abbreviations: 4/2: 4-weeks-on and 2-weeks-off; 2/1: 2-weeks-on and 1-week-off; RR: risk ratio; CI: confidence interval.

Table 3 Top 10 adverse effects (grade 3-4) associated with 2/1 versus 4/2.

\begin{tabular}{|c|c|c|c|c|c|c|c|}
\hline \multirow[t]{2}{*}{ Adverse effects } & \multirow{2}{*}{$\begin{array}{l}\text { No. of } \\
\text { studies }\end{array}$} & \multirow{2}{*}{$\begin{array}{c}\text { 2/1 group } \\
\text { (event/total) }\end{array}$} & \multirow{2}{*}{$\begin{array}{l}\text { 4/2 group } \\
\text { (event/total) }\end{array}$} & \multirow[t]{2}{*}{$\mathrm{RR}(95 \% \mathrm{CI})$} & \multirow{2}{*}{$\begin{array}{c}\mathrm{P} \\
\text { value }\end{array}$} & \multicolumn{2}{|c|}{ Heterogeneity } \\
\hline & & & & & & $\begin{array}{l}I^{2} \\
(\%)\end{array}$ & $\begin{array}{c}\mathrm{P} \\
\text { value }\end{array}$ \\
\hline Leukopenia & 4 & $12 / 135$ & $18 / 150$ & $\begin{array}{c}0.76[0.37 \\
1.57]\end{array}$ & 0.46 & 34 & 0.21 \\
\hline $\begin{array}{l}\text { Thrombocytopenia } \\
\text { /Platelet disorder }\end{array}$ & 8 & $13 / 255$ & $41 / 448$ & $\begin{array}{c}0.53[0.29 \\
0.98]\end{array}$ & 0.04 & 0 & 0.72 \\
\hline Hand-foot syndrome & 8 & $21 / 255$ & $56 / 451$ & $\begin{array}{c}0.61[0.38 \\
0.98]\end{array}$ & 0.04 & 16 & 0.31 \\
\hline Neutropenia & 7 & $19 / 191$ & $33 / 208$ & $\begin{array}{c}0.62[0.37 \\
1.04]\end{array}$ & 0.07 & 0 & 0.46 \\
\hline Anemia & 6 & $15 / 190$ & $16 / 210$ & $\begin{array}{c}1.02[0.52 \\
1.98]\end{array}$ & 0.96 & 0 & 0.67 \\
\hline Hypothyroidism & 6 & $2 / 208$ & $9 / 411$ & $\begin{array}{c}0.58[0.17 \\
1.95]\end{array}$ & 0.38 & 0 & 0.67 \\
\hline Stomatitis/Mucositis & 5 & $4 / 161$ & $23 / 349$ & $\begin{array}{c}0.38[0.13 \\
1.11]\end{array}$ & 0.08 & 0 & 0.74 \\
\hline Hypertension & 8 & $15 / 255$ & $53 / 451$ & $\begin{array}{c}0.45[0.26 \\
0.77]\end{array}$ & 0.004 & 0 & 0.71 \\
\hline Fatigue & 8 & $14 / 255$ & $57 / 451$ & $\begin{array}{c}0.42[0.24 \\
0.73]\end{array}$ & 0.002 & 0 & 0.88 \\
\hline $\begin{array}{l}\text { Abdominal pain } \\
\text { /Diarrhea }\end{array}$ & 6 & $8 / 208$ & $24 / 408$ & $\begin{array}{c}0.75[0.39 \\
1.43]\end{array}$ & 0.38 & 49 & 0.08 \\
\hline
\end{tabular}

Abbreviations: 4/2: 4-weeks-on and 2-weeks-off; 2/1: 2-weeks-on and 1-week-off; RR: risk ratio; CI: confidence interval.

Table 4 Subgroup analysis for progression-free survival, overall survival and objective response rate. 


\begin{tabular}{|c|c|c|c|c|c|c|c|c|c|c|c|c|}
\hline \multirow[t]{2}{*}{ Group } & \multicolumn{4}{|c|}{ PFS } & \multicolumn{4}{|c|}{ OS } & \multicolumn{4}{|c|}{ ORR } \\
\hline & $\begin{array}{l}\text { No. of } \\
\text { studies }\end{array}$ & HR $(95 \%$ CI) & $\mathrm{P}$ & $\begin{array}{c}I^{2} \\
(\%)\end{array}$ & $\begin{array}{l}\text { No. of } \\
\text { studies }\end{array}$ & HR $(95 \% \mathrm{CI})$ & $\mathrm{P}$ & $\begin{array}{l}I^{2} \\
(\%)\end{array}$ & $\begin{array}{c}\text { No. of } \\
\text { studies }\end{array}$ & RR $(95 \%$ CI $)$ & $\mathrm{P}$ & $\begin{array}{c}I^{2} \\
(\%)\end{array}$ \\
\hline Total & 8 & $\begin{array}{c}0.81[0.66, \\
0.99]\end{array}$ & 0.04 & 0 & 6 & $\begin{array}{c}1.00[0.95, \\
1.05]\end{array}$ & 0.97 & 0 & 5 & $\begin{array}{c}0.91[0.64, \\
1.29]\end{array}$ & 0.58 & 20 \\
\hline \multicolumn{13}{|l|}{ Nation } \\
\hline East Asia & 5 & $\begin{array}{c}0.75[0.58 \\
0.98]\end{array}$ & 0.03 & 20 & 3 & $\begin{array}{c}1.02[0.69, \\
1.50]\end{array}$ & 0.93 & 0 & 4 & $\begin{array}{c}0.92[0.63, \\
1.34]\end{array}$ & 0.65 & 39 \\
\hline Egypt & 1 & $\begin{array}{c}0.96[0.51 \\
1.82]\end{array}$ & 0.90 & NA & 1 & $\begin{array}{c}1.00[0.87, \\
1.15]\end{array}$ & 1 & NA & 1 & $\begin{array}{c}0.83[0.30 \\
2.31]\end{array}$ & 0.73 & NA \\
\hline Canada & 1 & $\begin{array}{c}0.84[0.41 \\
1.74]\end{array}$ & 0.64 & NA & 1 & $\begin{array}{c}0.63[0.26, \\
1.50]\end{array}$ & 0.3 & NA & NA & NA & NA & NA \\
\hline Italy & 1 & $\begin{array}{c}0.89[0.57 \\
1.40]\end{array}$ & 0.61 & NA & 1 & $\begin{array}{c}1.09[0.44 \\
2.68]\end{array}$ & 0.85 & NA & NA & NA & NA & NA \\
\hline \multicolumn{13}{|l|}{ Treatment line } \\
\hline First line & 4 & $\begin{array}{c}0.76[0.58 \\
1.00]\end{array}$ & 0.05 & 0.37 & 3 & $\begin{array}{c}0.96[0.61 \\
1.51]\end{array}$ & 0.87 & 0 & 2 & $\begin{array}{c}0.57[0.31 \\
1.02]\end{array}$ & 0.06 & 0 \\
\hline $\begin{array}{l}\text { First and second } \\
\text { line }\end{array}$ & 1 & $\begin{array}{c}0.84[0.41 \\
1.74]\end{array}$ & 0.64 & NA & 1 & $\begin{array}{c}0.63[0.26 \\
1.50]\end{array}$ & 0.30 & NA & NA & NA & NA & NA \\
\hline Unclear & 3 & $\begin{array}{c}0.87[0.63 \\
1.22]\end{array}$ & 0.43 & 0 & 2 & $\begin{array}{c}1.00[0.95 \\
1.05]\end{array}$ & 0.97 & 0 & 3 & $\begin{array}{c}1.20[0.77 \\
1.89]\end{array}$ & 0.42 & 0 \\
\hline \multicolumn{13}{|l|}{ Initial dosage } \\
\hline $50 \mathrm{mg} / \mathrm{d}$ & 5 & $\begin{array}{c}0.76[0.59 \\
0.97]\end{array}$ & 0.03 & 0 & 4 & $\begin{array}{c}1.00[0.95, \\
1.05]\end{array}$ & 0.99 & 0 & 3 & $\begin{array}{c}1.20[0.77 \\
1.89]\end{array}$ & 0.42 & 0 \\
\hline $50 / 37.5 / 25 \mathrm{mg} / \mathrm{d}$ & 1 & $\begin{array}{c}0.54[0.21 \\
1.38]\end{array}$ & 0.20 & NA & NA & NA & NA & NA & 1 & $\begin{array}{c}0.62[0.30 \\
1.25]\end{array}$ & 0.18 & NA \\
\hline Unclear & 2 & $\begin{array}{c}0.99[0.68 \\
1.43]\end{array}$ & 0.94 & 0 & 2 & $\begin{array}{c}0.93[0.54 \\
1.63]\end{array}$ & 0.81 & 0 & 1 & $\begin{array}{c}0.50[0.18 \\
1.40]\end{array}$ & 0.19 & NA \\
\hline \multicolumn{13}{|l|}{ Study quality a } \\
\hline High quality & 5 & $\begin{array}{c}0.80[0.64 \\
1.01]\end{array}$ & 0.06 & 16 & 4 & $\begin{array}{c}1.03[0.72, \\
1.47]\end{array}$ & 0.87 & 0 & 3 & $\begin{array}{c}1.05[0.67, \\
1.64]\end{array}$ & 0.83 & 35 \\
\hline Medium quality & 3 & $\begin{array}{c}0.81[0.53 \\
1.25]\end{array}$ & 0.35 & 0 & 2 & $\begin{array}{c}1.00[0.95 \\
1.05]\end{array}$ & 0.95 & 7 & 2 & $\begin{array}{c}0.69[0.38 \\
1.24]\end{array}$ & 0.21 & 0 \\
\hline \multicolumn{13}{|l|}{ Study design } \\
\hline RCT & 1 & $\begin{array}{c}0.75[0.44 \\
1.27]\end{array}$ & 0.29 & NA & 1 & $\begin{array}{c}1.15[0.64 \\
2.05]\end{array}$ & 0.64 & NA & 1 & $\begin{array}{c}1.42[0.80 \\
2.51]\end{array}$ & 0.23 & NA \\
\hline RS & 7 & $\begin{array}{c}0.82[0.65 \\
1.02] \\
\end{array}$ & 0.07 & 0 & 5 & $\begin{array}{c}1.00[0.95 \\
1.05] \\
\end{array}$ & 0.94 & 0 & 4 & $\begin{array}{c}0.71[0.45 \\
1.12] \\
\end{array}$ & 0.14 & 0 \\
\hline
\end{tabular}

Abbreviations: PFS: progression-free survival; OS: overall survival; ORR: objective response rate; HR: hazard ratio; RR: risk ratio; CI: confidence interval; NA: not available.

a: study quality was evaluated using the Newcastle-Ottawa Scale for retrospective observational studies and the Jadad scale for randomized controlled trials.

\section{Figures}




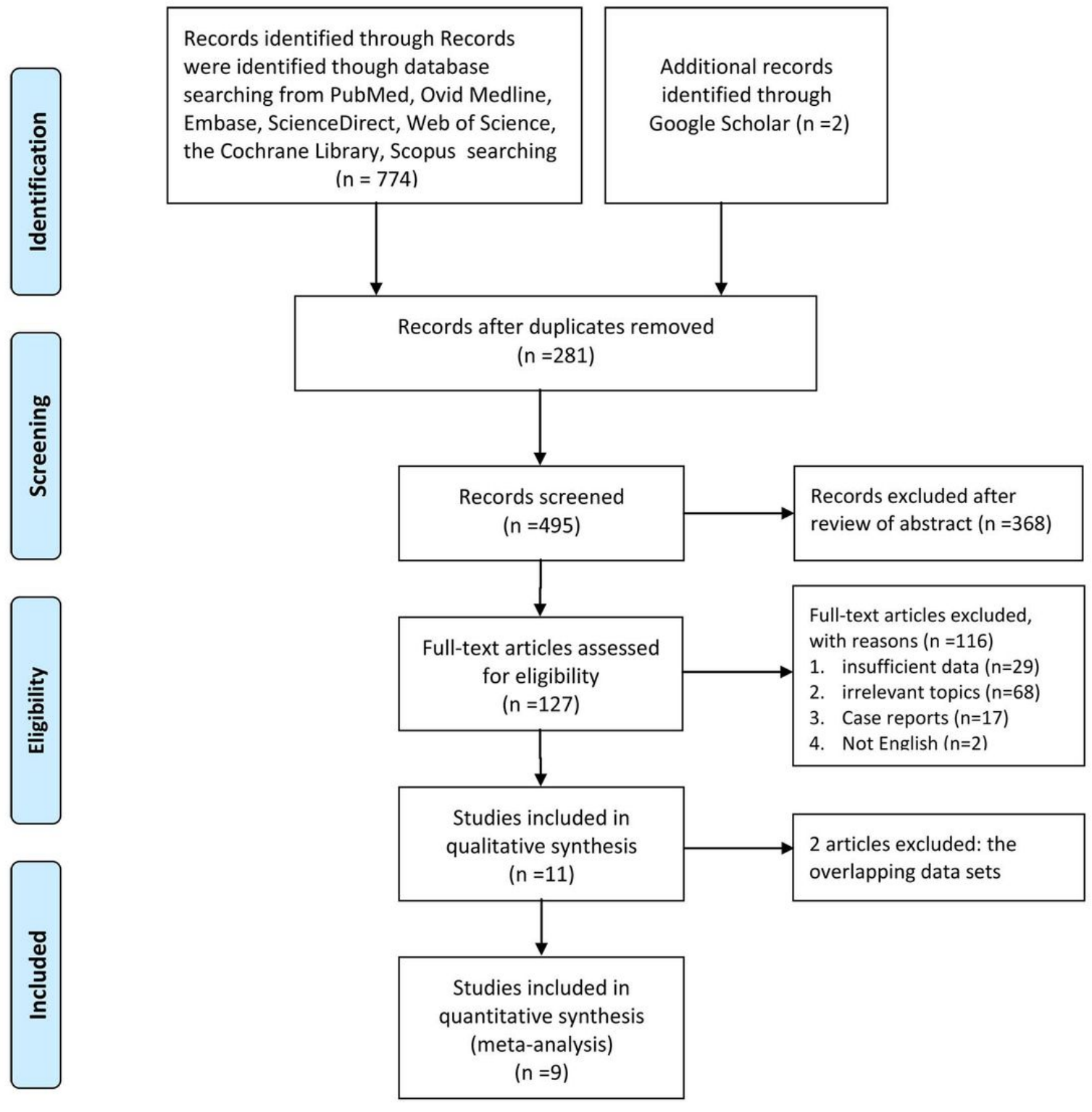

Figure 1

Flow chart of study selection. 


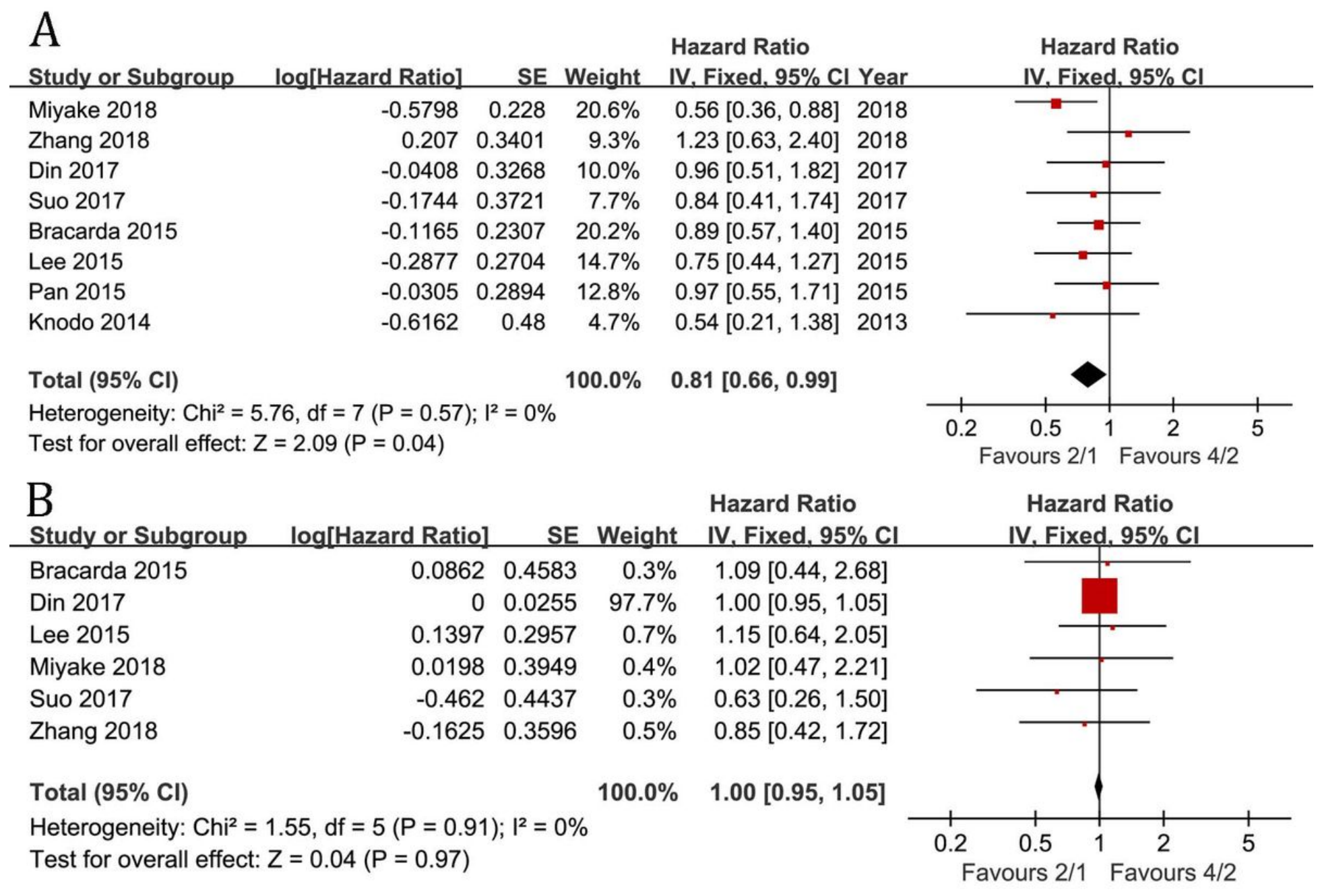

Figure 2

Forest plot of PFS (A) and OS (B) associated with $2 / 1$ versus $4 / 2$. 


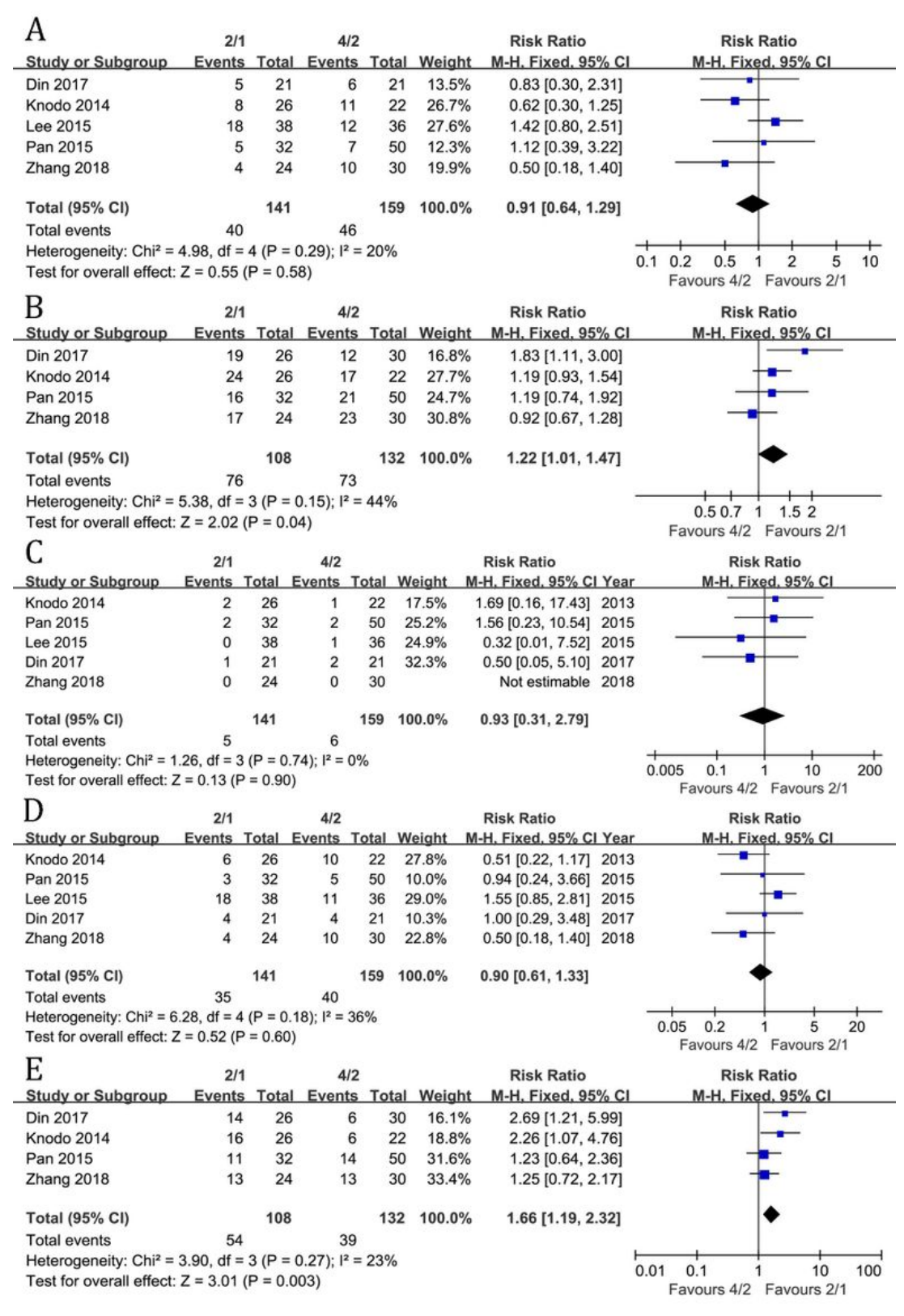

\section{Figure 3}

Forest plots of ORR (A), DCR (B), CR (C), PR (D), and SD (E) associated with 2/1 versus 4/2. 


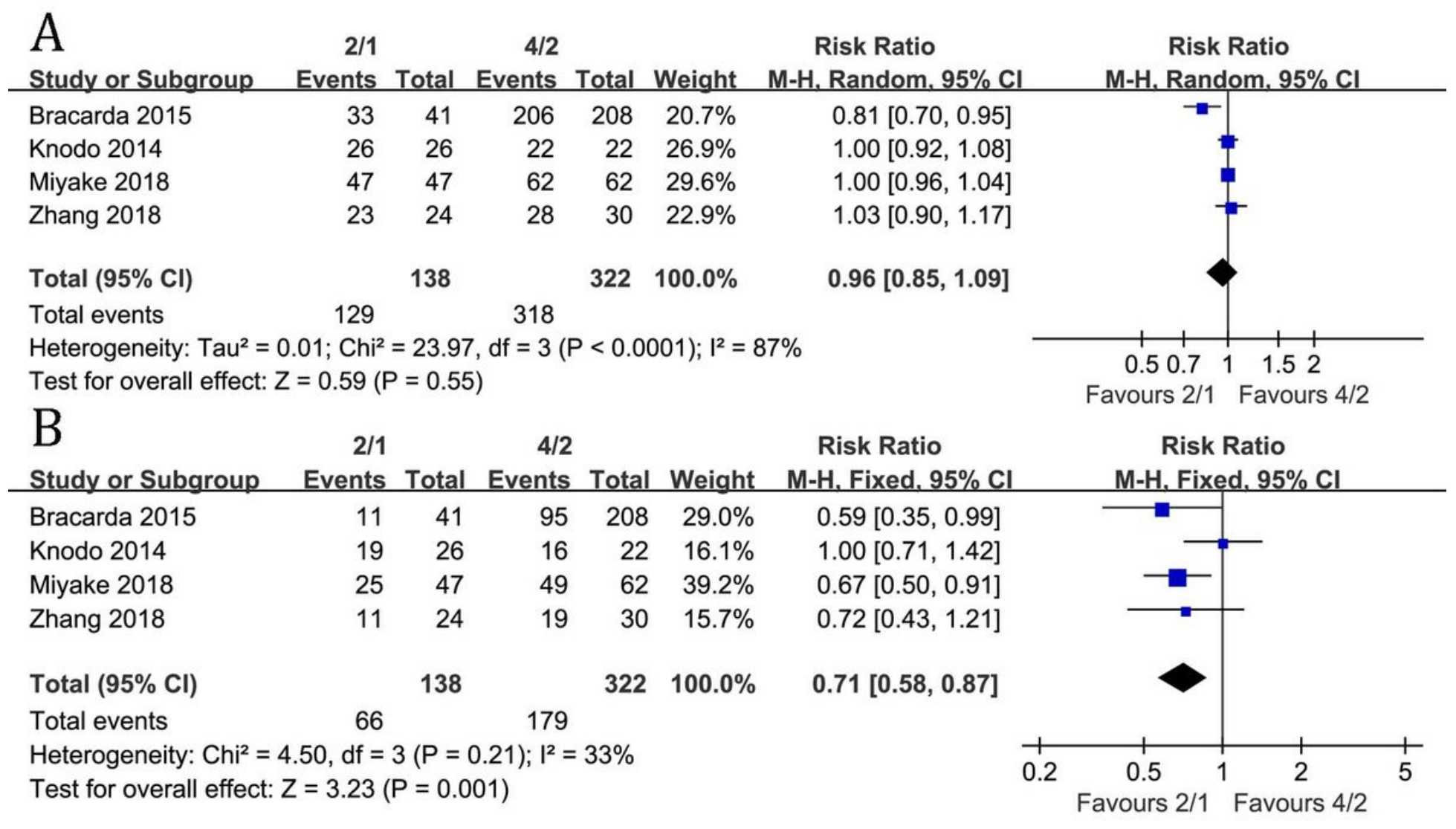

\section{Figure 4}

Forest plots of RR of any grade AEs (A), grade 3-4AEs (B) associated with 2/1 versus 4/2. 


\section{A}

2/1

$4 / 2$

Risk Ratio

Risk Ratio

Study or Subgroup

Events

\section{Knodo 2014}

Lee 2015

Miyake 2018

Total $(95 \% \mathrm{Cl})$

Total events

Heterogeneity: $\mathrm{Tau}^{2}=0.05 ; \mathrm{Chi}^{2}=4.79, \mathrm{df}=2(\mathrm{P}=0.09) ; \mathrm{I}^{2}=58 \%$

Test for overall effect: $Z=0.16(P=0.87)$

$74 \quad 89$

$\begin{array}{rrrrrr}20 & 26 & 12 & 22 & 27.5 \% & 1.41[0.91,2.18] \\ 12 & 38 & 17 & 36 & 19.7 \% & 0.67[0.37,1.20] \\ 42 & 47 & 60 & 62 & 52.8 \% & 0.92[0.83,1.03] \\ & & & & & \\ & 111 & & 120 & 100.0 \% & 0.97[0.71,1.34]\end{array}$

B

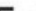

ts Tota vents Total Weight

$41 \quad 62 \quad 73.1 \%$

$\begin{array}{lrrrrrr}\text { Knodo 2014 } & 7 & 26 & 12 & 22 & 26.9 \% & 0.49[0.24,1.03] \\ \text { Miyake 2018 } & 20 & 47 & 41 & 62 & 73.1 \% & 0.64[0.44,0.94]\end{array}$

Risk Ratio

M-H, Fixed, $95 \% \mathrm{Cl}$

Total $(95 \% \mathrm{Cl})$ 73

$84 \quad 100.0 \%$

Total events 27 53

Heterogeneity: $\mathrm{Chi}^{2}=0.40, \mathrm{df}=1(\mathrm{P}=0.53) ; \mathrm{I}^{2}=0 \%$

Test for overall effect: $Z=2.94(P=0.003)$

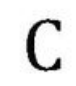

$0.60[0.43,0.84]$

Risk Ratio

Study or Subgroup

Events

\section{Lee 2015}

Miyake 2018

Total $(95 \% \mathrm{Cl})$

Total events

Heterogeneity:

Test for overall effect: $Z=0.66(P=0.51)$

$\begin{array}{rrrrrr}\text { nnts } & \text { Total } & \text { Events } & \text { Total } & \text { Weight } & \text { M-H. Random, 95\% C } \\ 33 & 38 & 35 & 36 & 54.1 \% & 0.89[0.78,1.02] \\ 4 & 47 & 17 & 62 & 45.9 \% & 0.31[0.11,0.86] \\ & & & & & \\ 37 & 85 & & 98 & 100.0 \% & 0.55[0.09,3.21]\end{array}$

; $\mathrm{Ch}^{2}=11.83, \mathrm{df}=1(\mathrm{P}=0.0006) ; \mathrm{I}^{2}=92 \%$

\author{
.
}

